Article

\title{
Genetic Diversity of Aquatic Ranunculus (Batrachium, Ranunculaceae) in One River Basin Caused by Hybridization
}

\author{
Jurgita Butkuvienė ${ }^{1,2, * \mathbb{C}}$, Zofija Sinkevičienė ${ }^{3}$, Donatas Naugžemys ${ }^{2}$, Donatas Žvingila ${ }^{1}(\mathbb{D}$, \\ Audrius Skridaila ${ }^{2}$ and Alexander A. Bobrov ${ }^{4}$ \\ 1 Life Sciences Center, Vilnius University, Saulètekio av. 7, LT-10222 Vilnius, Lithuania; \\ donatas.zvingila@gf.vu.lt \\ 2 Botanical Garden, Vilnius University, Kairènų Str. 43, 01100 Vilnius, Lithuania; genetikas@gmail.com (D.N.); \\ audrius.skridaila@bs.vu.lt (A.S.) \\ 3 Nature Research Centre, Institute of Botany, Žaliuju Ežerų Str. 49, 12200 Vilnius, Lithuania; \\ zofijasin@gmail.com \\ 4 Papanin Institute for Biology of Inland Waters RAS, Borok, Nekouz distr., 152742 Yaroslavl reg., Russia; \\ lsd@ibiw.yaroslavl.ru \\ * Correspondence: jurgita.makaviciute@gmail.com; Tel.: +370-52398262
}

Received: 29 September 2020; Accepted: 26 October 2020; Published: 28 October 2020

\begin{abstract}
Aquatic Ranunculus (sect. Batrachium) include homophyllous and heterophyllous plants. The development of floating leaves may be induced by genetic mechanisms or/and environmental conditions and this fact complicates the morphologically based identification of species. DNA-based studies provide the opportunity to expand the knowledge of this complicated group. We studied heterophyllous Ranunculus with well-developed capillary and intermediate leaves and visually homophyllous plants with capillary leaves from a single river basin, with the aim to evaluate their genetic polymorphism and taxonomic status-whether the plants with well-developed and weakly expressed intermediate leaves belong to different forms (taxa) or if they just express morphological variation of one or two taxa in a specific, very variable river environment. The studied heterophyllous and homophyllous plants from different rivers showed high genetic differentiation and a low level of genetic diversity within these groups. The molecular analysis did not reveal any inter simple sequence repeat (ISSR) polymorphism associated with the development of intermediate leaves. An analysis of nuclear ribosomal internal transcribed spacers ITS1-2 sequences revealed several ribotypes, which indicated the genetic heterogeneity of studied plants and indirectly confirmed the hybrid origin of some of them. Sterile plants originated from crossing of $R$. circinatus and R. penicillatus were discovered in the Skroblus River; however, identification of the parental species was impeded by the polymorphism detected. For this reason, cytological studies were performed and allowed confirmation of the hybrid origin of these plants.
\end{abstract}

Keywords: aquatic plants; Ranunculus sect. Batrachium; hybridization; molecular identification

\section{Introduction}

Water crowfoots, Ranunculus (sect. Batrachium), are characterized as morphologically heterogeneous and sensitive to changes in the environment [1,2]. This evolutionary young group of aquatic buttercups is well known for its intricate taxonomy determined by phenotypic plasticity, polyploidy, interspecific hybridization, and persistence by different ways of propagation [1,3-8].

River Ranunculus sect. Batrachium forms are a very complicated group for identification. In particular, the Ranunculus penicillatus complex combines different allopolyploids and hybrids $[1,4,5,9]$. 
As maintained by the classic literature [1], three groups of plants were distinguished within this taxon by leaf morphology: (1) homophyllous plants that produce only submerged, long capillary leaves; (2) homophyllous plants that produce only submerged, rather rigid capillary leaves; and (3) heterophyllous plants that produce capillary, floating, and intermediate leaves. In a recent study of Ranunculus sect. Batrachium [7], the homophyllous plants with capillary leaves were treated as Ranunculus pseudofluitans (Syme) Newbould ex Baker and Foggitt with flaccid leaves and R. vertumnus (C.D.K. Cook) Luferov with rather rigid leaves; the heterophyllous plants were treated as R. penicillatus (Dumort.) Bab., with the note that this name should be applied to the amphidiploid species originating from the crossing of $R$. fluitans and R. peltatus. Heterophyllous R. penicillatus is distributed in eastern and western European rivers but remains insufficiently understood because of its morphological heterogeneity and presumably hybridogenous origin [1,4,5,7-9]. Prančl et al. [8] indicated that genome size is a good marker for distinguishing of the most traditionally recognized species, but problems arise with difficult taxa, such as R. penicillatus, which is a group of different allopolyploids or hybrids.

The distribution of $R$. penicillatus and its occurrence in the flowing waters of the Baltic region including Lithuania remain unclear. Tzvelev [10] recorded heterophyllous $R$. penicillatus only in Latvia; additionally, the authors in [9] recorded it in Estonia.

During studies of aquatic Ranunculus in Lithuanian rivers, the unusual plants from the Merkys River basin (Southeast Lithuania) received special attention. They differed by the occurrence of more or less developed intermediate leaves and the absence of true floating leaves. One population in the Skroblus River has been known since 1983 and randomly observed to date. Ranunculus plants from this river are characterized by the permanent occurrence of capillary and intermediate leaves during the flowering period; however, true floating leaves have never been observed. Plants with solitary and sometimes hardly visible intermediate leaves or with capillary leaves only are observed in other rivers of this basin, in particular in the Ula River. The specimens in herbaria with intermediate leaves usually were tentatively identified as R. penicillatus, whereas with capillary leaves, only as R. pseudofluitans or $R$. fluitans. Cook [1] described many fertile and sterile hybrids and he suggested that intermediate leaves are frequently developed by hybrid forms between homophyllous and heterophyllous species. It has been shown [4-7] that interspecific hybridization within Ranunculus sect. Batrachium can make margins among species very unclear. This issue hampers determination of taxa based solely on morphological characters. Molecular methods have been previously used for the characterization of other aquatic plant species known for their phenotypic plasticity and taxonomic uncertainty [5,8,11-14]. The data obtained from molecular research could simplify the identification of species and provide a better understanding of their genetic properties and origins. Ranunculus sect. Batrachium has previously been the subject of molecular research [4-6,15]; however, in Lithuania, this type of investigation was started only recently [16].

For this DNA-based and cytological study, we selected heterophyllous (with well-developed and weakly developed intermediate leaves) and homophyllous (with capillary leaves only) aquatic Ranunculus plants from the different Merkys basin rivers, with the aim to assess whether the plants with well-developed and weakly expressed intermediate leaves belong to the different forms (taxa) or if they just express morphological variation of one or two taxa in a specific, very variable river environment.

\section{Results}

\subsection{Genetic Diversity Based on ISSR-PCR Analysis}

Inter simple sequence repeat (ISSR) polymorphism was assessed for all 33 plants sampled. A total of 53 bands were identified, of which 39 were polymorphic. Our attempt to identify morphotype-specific ISSR bands with any of the 27 tested oligonucleotide primers was unsuccessful. Specific ISSR bands for heterophyllous (Skroblus and Ula rivers) and homophyllous (Gruda and Ula) plants were not identified. All plant groups (from Gruda, Skroblus, and Ula rivers) showed similar genetic diversity parameters (Table 1). 
Table 1. The genetic diversity parameters of different Ranunculus sect. Batrachium populations. Band richness based on eight individuals (Br); polymorphic loci at the 5\% level (PLP 5\%); expected heterozygosity under Hardy-Weinberg genotypic proportions (He); gene diversity (h); Shannon's information index (I); SD—standard deviation; SE—standard error.

\begin{tabular}{cccccc}
\hline Population & $\mathbf{h} \pm \mathbf{S D}$ & $\mathbf{I} \pm \mathbf{S D}$ & $\mathbf{B r}[8]$ & PLP 5\% & He \pm SE \\
\hline Gruda & $0.06 \pm 0.13$ & $0.09 \pm 0.19$ & 1.19 & 0.23 & $0.06 \pm 0.02$ \\
Skroblus & $0.07 \pm 0.15$ & $0.12 \pm 0.22$ & 1.20 & 0.23 & $0.07 \pm 0.02$ \\
Ula & $0.06 \pm 0.14$ & $0.10 \pm 0.21$ & 1.18 & 0.23 & $0.06 \pm 0.02$ \\
\hline
\end{tabular}

Three plant groups showed an identical proportion of polymorphic loci at the 5\% level (Table 1). All plant groups exhibited a similar measure of band richness (Br), ranging from 1.19 (Ula) to 1.20 (Skroblus), and expected heterozygosity (He), ranging from 0.06 (Gruda) to 0.07 (Skroblus). The lowest value of Shannon's information index was also found in Gruda (0.09), and the highest index was in Skroblus (0.12).

Wright's fixation index showed very high genetic differentiation among the studied populations $($ Fst $=0.796)$. In pairwise comparisons, the highest value of genetic differentiation was found between Gruda and Ula plants (Fst $=0.846)$, whereas the lowest value was between Skroblus and Ula plants $($ Fst $=0.709)$. Genetic differentiation between Gruda and Skroblus plants was $0.834($ Fst $=0.834)$.

We also used hierarchical analysis of molecular variance (AMOVA) to reveal possible differences between the different phenotypic groups (heterophylous and homophyllous) of plants from these populations (Fst $=0.02, p<0.05$ ). Hierarchical AMOVA showed non-significant genetic differentiation among groups of homophyllous and heterophyllous plants (PhiRT $=0.019 ; p=0.3$ ) (Table 2). The highest genetic differentiation was among the plant groups from different rivers (81\%). Within the groups, the molecular variance component reached only 17\% (Table 2).

Table 2. Analysis of molecular variance (AMOVA) for different groups of Ranunculus section Batrachium. Df-degrees of freedom; SS—sum of squared deviation; MS—mean squared deviation; Est.Var.-estimated variance; \%-percentage.

\begin{tabular}{lccccccc}
\hline Source & df & SS & MS & Est. Var. & $\%$ & Value & $p$ \\
\hline Among phenotypic groups & 1 & 73.859 & 73.859 & 0.165 & $2 \%$ & & \\
Among plants groups from different rivers & 2 & 143.343 & 71.671 & 6.862 & $81 \%$ & \\
Within plants groups from different rivers & 37 & 63.725 & 1.722 & 1.722 & $17 \%$ & \\
\hline Total & 40 & 280.927 & & 8.749 & $100 \%$ & & \\
\hline PhiRT & & & & & & 0.019 & 0.298 \\
\hline
\end{tabular}

\subsection{Ribosomal DNA ITS Region and Plastid rpl32-trnL Region Analysis}

After comparison of the 26 established ribosomal DNA internal transcribed spacer (ITS) region sequences, a $573 \mathrm{bp}$ long alignment was obtained. Analysis of sequencing data revealed 37 variable and 536 conserved sites. The 30 sites were potentially parsimony informative in the entire dataset. Only one site was identified as a single base insertion/deletion (Table 3 (30 bp position)). A single nucleotide polymorphism was detected at alignment positions 202 (R. penicillatus (KR995528, U5, U9, U11, and U12), 444 (Ranunculus circintatus G6), 445 (KR995528, U5, U9, U11, and U12), and 476 (KR995528, U5, U9, U11, and U12). 
Table 3. Sequence variation in the internal transcribed spacer (ITS) region of Ranunculus sect. Batrachium (14 sequences from populations Gruda, Skroblus (marked by grey color), and Ula and 12 sequences from the GenBank ${ }^{\circledR}$ database). G—Gruda River (homophyllous plants); S-Skroblus River (heterophyllous plants); U—Ula River (homophyllous and heterophyllous plants).

\begin{tabular}{|c|c|c|c|c|c|c|c|c|c|c|c|c|c|c|c|c|c|c|c|c|c|c|c|c|c|c|c|}
\hline & & & & & & & 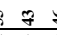 & & 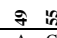 & & 506 & 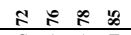 & & 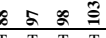 & & & & 10 & $\begin{array}{ll}C & A \\
C\end{array}$ & 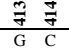 & $\frac{7}{7}=7$ & $\begin{array}{l}\frac{7}{7}+\frac{7}{C} \\
\text { T }\end{array}$ & $\frac{5}{5}$ & & in & & \\
\hline$\frac{\text { Specimen }}{R \text { fluiturn }}$ & $\begin{array}{ll}\text { GB ascession number } \\
\text { KR } 209626\end{array}$ & $\begin{array}{ll}\text { Herbarium specimen } \\
\text { KR } 0426263\end{array}$ & $\begin{array}{l}\text { Origin } \\
\text { NE Plond. Robrove ta } 2015\end{array}$ & $\mathrm{C}$ & & $\mathrm{sc}$ & & & & & $\mathrm{TCC}$ & $\begin{array}{lllll}C & A & A & T \\
\end{array}$ & & & & & & & & & & & & & & & $T$ \\
\hline $\begin{array}{l}R \text {. fluitans } \\
R \text { flutions } \mathrm{Gl}\end{array}$ & KR996526 & KRA0426263 & 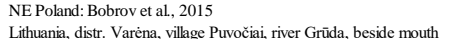 & & & & & & & & & & & & & & & & & & & & & & & & \\
\hline R. fluitans $\mathrm{Gl}$ & MH924781 & WI, s.n. & & & & & & & & & & & & & & & & & & & & & & & & & \\
\hline $\begin{array}{l}\text { R.flutituns G11 } 1 \\
\text { R.flutans } \mathrm{M} 2\end{array}$ & $\begin{array}{l}\text { MHH24480 } \\
\text { MH924799 }\end{array}$ & $\begin{array}{l}\text { WI, s.n. } \\
\text { WI. s.n. }\end{array}$ & 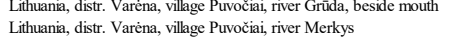 & & & & & & & & & & & & & & & & & & & & & & & & \\
\hline R. fluitans $\mathrm{M} 8$ & MH924778 & WI, s.n. & Lithuania, distr. Varèna, village Puvočiai, river Merkys & & & & & & & & & & & & & & & & & & & & & & & & \\
\hline R. fluitans M10 & МT015513 & WI, s.n. & Lithuania, distr. Varèna, vilageg Puwoǒ́a, river Merkys & & & & & & & & & & & & & & & & & & & & & & & & \\
\hline R. penicillatus & KR996528 & KRA0426262 & W Poland: Bobrov et al, 2015 & & & & & & & & & 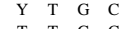 & & & $\mathrm{T}$ & & & & & & & & & & & & c \\
\hline $\begin{array}{l}\text { R. penicillatus U5 } \\
\text { R nemiclaus }\end{array}$ & MH924769 & WI, s.n, P33606 & Lithuania, distr. Variena, near the village Manciagirie, beside "Vlos akis" & $T_{T}$ & & & G & & & & c & $\begin{array}{llll}T & \text { T } & \text { G } & \text { C } \\
& T & & \end{array}$ & & & $\mathrm{C}$ & $\mathrm{G}$ & & & $\mathrm{T}$ & & & C & A & A & & & $\mathrm{C}$ \\
\hline $\begin{array}{l}\text { R. penicillatusu } \mathrm{U9} \\
\text { R. penicllatus } \mathrm{U} 11\end{array}$ & $\begin{array}{l}\text { MHH242470 } \\
\text { M992471 }\end{array}$ & $\begin{array}{l}\text { WI s.n. } \\
\text { WI, s.n. P33604 }\end{array}$ & 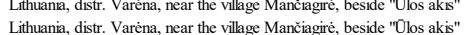 & $\begin{array}{l}\mathrm{T} \\
\mathrm{T}\end{array}$ & & & $\mathrm{G}_{\mathrm{G}}^{\mathrm{B}}$ & & & c & $\begin{array}{c}c \\
c\end{array}$ & $\begin{array}{llll}T & T & G & C \\
T & T & G & C\end{array}$ & & & $\begin{array}{l}\mathrm{C} \\
\mathrm{C}\end{array}$ & G & & $\begin{array}{ll}\mathrm{G} \\
\mathrm{G}\end{array}$ & $\begin{array}{c}\mathrm{T} \\
\mathrm{T}\end{array}$ & & & $\begin{array}{l}\mathrm{C} \\
\mathrm{C}\end{array}$ & ${ }_{A}^{A}$ & A & & & $\begin{array}{c}\mathrm{C} \\
\mathrm{C}\end{array}$ \\
\hline R. penicillatus U12 & MH924772 & $\begin{array}{l}\text { W1, s.n, , } 33004 \\
\text { WI, s.n. }\end{array}$ & Lithuania, distr. Varena, near the vilage Manciagrie, beside "Ülos akis" & $\mathrm{T}$ & & & $\mathrm{G}$ & & & & c & $\mathrm{T} \quad \mathrm{T} \quad \mathrm{G} \quad \mathrm{C}$ & & & $\mathrm{c}$ & & & & & & & $\mathrm{C}$ & A & & & & $\mathrm{c}$ \\
\hline $\begin{array}{l}\text { R.circinatus } \\
\text { Retiz }\end{array}$ & KF719061 & KRA0347700 & C Pohand: Bobrov et al, 2015 & & & & G & & G & & & 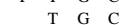 & & & & & & & & & & & & & & & \\
\hline R.circinatus G6 & MT015512 & $\begin{array}{l}\text { WI, s.n. } \\
\text { WI }\end{array}$ & 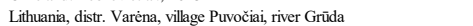 & $\mathrm{T}$ & & & $\mathrm{G}$ & & $\mathrm{G}$ & & $\mathrm{c}$ & $\mathrm{T} \mathrm{G} \mathrm{C}^{-1}$ & r & 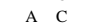 & & $\mathrm{G}$ & & $\mathrm{G}$ & & $\mathrm{A}$ T & & $\mathrm{T}$ & & & & & C \\
\hline Ranunculus hybrid S2 & MH924773 & WI, s.n. & Lithumani, distr. Varèna, vilage Kapiniškiai river Skroblus & $\mathrm{T}$ & & & $\mathrm{G}$ & & G & & $\mathrm{c}$ & T G C & & 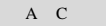 & & & & & & & & & & & & & \\
\hline Ranunculus hybrid S3 & МH924774 & WI, s.n. & Lithuania, distr. Varèna, village Kapiniskiai, river Skroblus & $\mathrm{T}$ & & & G & & $\mathrm{G}$ & & $\mathrm{c}$ & & & A C C & & T & & & & & & $\mathrm{C}$ & & A & & & c \\
\hline Ranunculus hybrid S8 & MH924775 & WL, s.n. P33603 & Lithuania, distr. Varéna, vilage Kapiniskiai, river Skroblus & $\mathrm{T}$ & & & $\mathrm{G}$ & & $\mathrm{G}$ & & $\mathrm{C}$ & T G C & & $\begin{array}{llll}A & C & C\end{array}$ & & T & & & & & & $\mathrm{C}$ & & A & & & $\mathrm{C}$ \\
\hline Ranunculus hybrid SIC & 0 MH924776 & WI, s.n. & Lithuania, distr. Vareña, village Kapiniškiaia river Skroblus & & & & $\mathrm{G}$ & & $\mathrm{G}$ & & $\mathrm{c}$ & T G C & & $\begin{array}{lll}A & C & C \\
& & \end{array}$ & & T & & & & A T & & & & & & & $\mathrm{C}$ \\
\hline 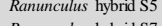 & MH924777 & WL, s.n. & Lithuania, distr. Varéna, vilage Kapiniskiai river Skroblus & & & & $\mathrm{G}$ & & $\mathrm{G}$ & & & & & & & & & & & A & & C & & A & & & \\
\hline Ranunculus hybrid S7 & MT015510 & $\begin{array}{ll}\text { Wi, s.n. } \\
\text { wy }\end{array}$ & Lithuania, distr. Varenna, vilage Kapiniškiaia river Skroblus & T & & & G & & & & & $\begin{array}{lllll}T & T & G & C \\
T & T & C\end{array}$ & & & $\mathrm{C}$ & $\mathrm{G}$ & & o & & & 1 & $\mathrm{C}$ & & A & & & c \\
\hline Ranunnculus hybrid S6 & MT015511 & WI, s.n. & Lithuania, distr. Varéna, village Kapiniškiai, river Skroblus & 1 & & & & & & & & T T G C & & & & & & & & & A & & & & & & \\
\hline R. schmalhausenii & KR996541 & IBIW, s.n. & NW Russia: Bobrov et al, 2015 & $\mathrm{~T}$ & & $\begin{array}{l}A T \\
\text { A }\end{array}$ & $\mathrm{G}$ & & & A & & $\begin{array}{ccc}\mathrm{T} & \mathrm{G} & \mathrm{C} \\
\mathrm{T} & \mathrm{C} & -\end{array}$ & & $Y^{Y}$ & & & & & $\mathrm{~T}$ & & & C & & $\mathrm{R}^{\mathrm{N}}$ & & & $\mathrm{C}$ \\
\hline 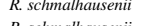 & $\begin{array}{l}\text { KR9965545 } \\
\text { KPR96559 }\end{array}$ & 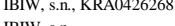 & NW Russia: Bobrov et al, 2015 & 1 & & $\begin{array}{l}R^{R} T T_{T} \\
T\end{array}$ & & & & & & $\begin{array}{lllllll}T & G & C \\
T\end{array}$ & & & & & & & & & & & & & & & $\mathrm{c}$ \\
\hline 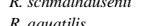 & $\begin{array}{l}\text { KRR960539 } \\
\text { KF719055 }\end{array}$ & 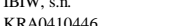 & 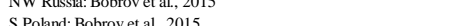 & & & ${ }^{A}{ }_{T}$ & a & & & & & $\begin{array}{lllllllll}1 & 0 & c\end{array}$ & & & & & & & & & & & & & & & \\
\hline $\begin{array}{l}\text { A. } \\
\text { R. aquatilis }\end{array}$ & KF719056 & KRA0410447 & Croatia: Bobrov et al., 2015 & $\mathrm{~T}$ & & & $\mathrm{G}$ & & $\mathrm{G}$ & & & T & & & & & & & & & & & & & & & \\
\hline R. baudotii & KF719058 & KRA0410448 & N Estonia: Bobrov et al, 2015 & & & & & & & & & 1 & & & & & & & & & & & & & & & \\
\hline
\end{tabular}


On the basis of the polymorphism of the ITS region sequences, seven different Ranunculus ribotypes were differentiated. Three individuals from the Gruda River presented two different ribotypes (G1, G11 one ribotype, and G6 another one). Seven plants from the Skroblus River belonged to five different ribotypes. All plants from the Ula River had the same ribotype. The identified sequences are deposited in the GenBank ${ }^{\circledR}$ database (accessions numbers MH924769-MH924781, MT015510-MT015513).

The sequences homologous for the obtained ITS sequences were searched in GenBank ${ }^{\circledR}$, and 16 sequences were extracted. Individual variation and relation among some Ranunculus detected based on polymorphism of the ITS region is shown in the dendrogram (Figure 1).

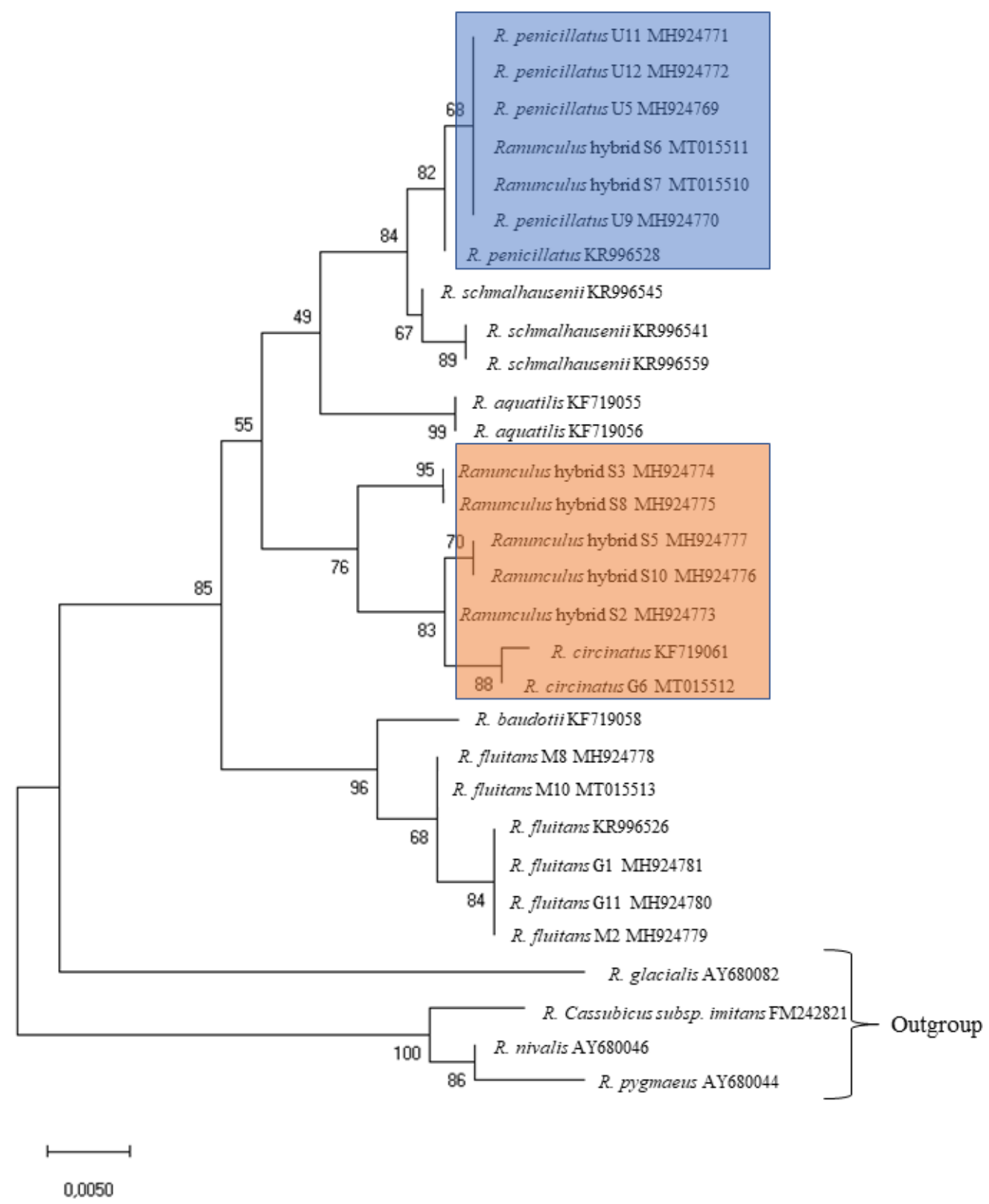

Figure 1. The ITS tree built using the maximum likelihood (ML) method showing relationships between 30 accessions of Ranunculus sect. Batrachium. Numbers indicate support values of ML analysis. Bootstrap support values were computed for 1000 replicates. The blue cluster combines R. penicillatus from the Ula River and Ranunculus hybrid sequences from the Skroblus River with the same ribotype of R. penicillatus; the orange cluster combines R. circinatus from the Gruda River and Ranunculus hybrid sequences from the Skroblus River with the same or very similar ribotypes of $R$. circinatus KF719061. 
Homophyllous plants with flaccid capillary leaves only with a few ultimate segments from the Gruda River (G1 (MH924781), G11 (MH924780)) showed the highest similarity to Ranunculus fluitans (Figure 1). These specimens shared one ribotype with samples from the GenBank ${ }^{\circledR}$ database- $\mathrm{M} 2$ (MH924779) and R. fluitans (KR996526). Very high similarity to M2 was detected in the M8 (MH924778) and M10 (MT015513) individuals (Figure 1).

Homophyllous plants with rigid capillary leaves only with numerous ultimate segments from the Gruda River showed the highest similarity to R. circinatus (Figure 2). The specimen G6 (accession number MT015512) shared a very similar ribotype with the sample of $R$. circinatus obtained from the GenBank ${ }^{\circledR}$ database (KF719061) (Figure 1).

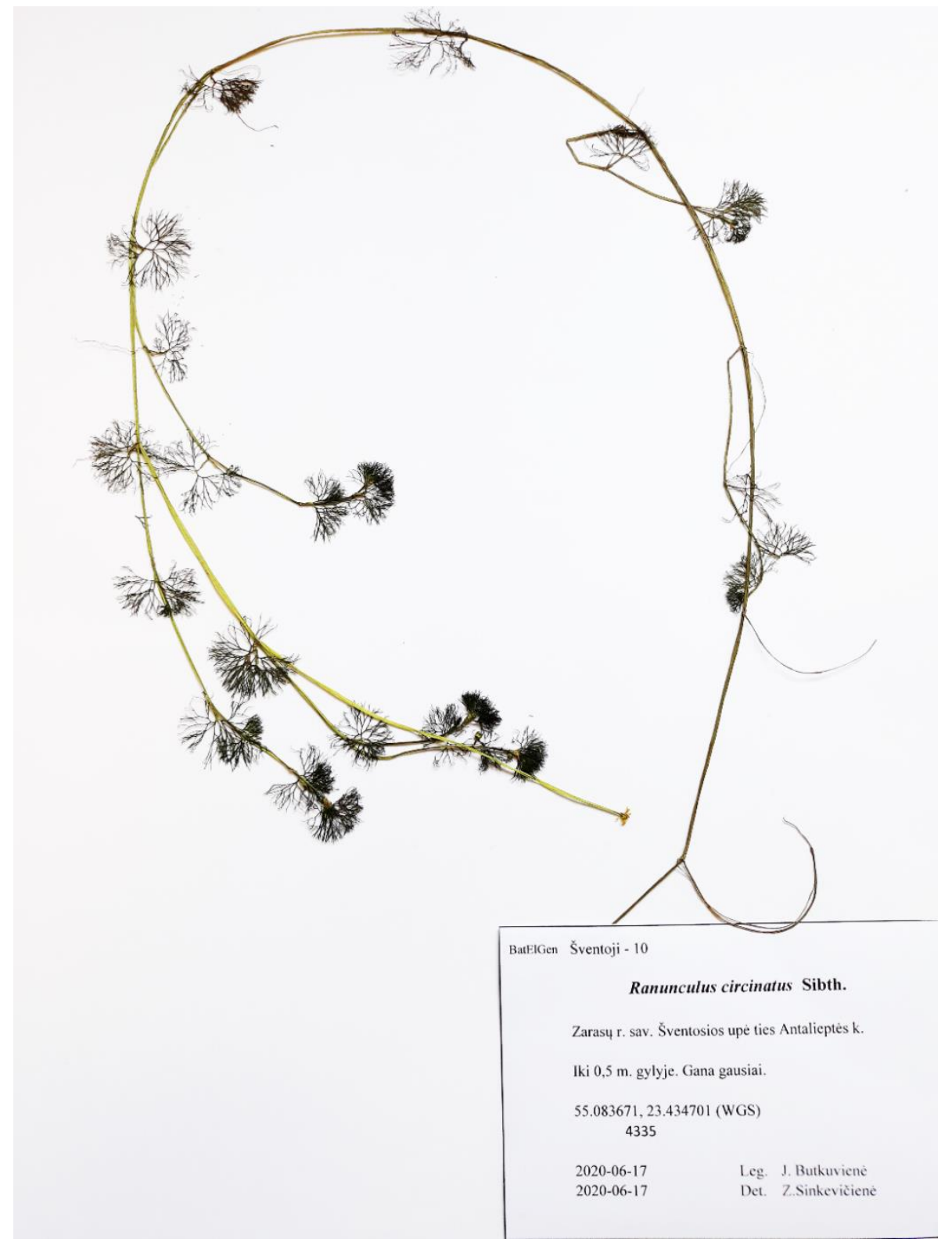

Figure 2. General appearance of Ranunculus circinatus.

In the Ula River, homophyllous individuals with flaccid capillary leaves with numerous ultimate segments (U9, U11, U12) were mostly presented (Figure 3) as well as one individual (U5) additionally with intermediate weakly developed leaves (Figure 4). Both kinds of plants were fertile (numerous heads with ripe fruits). All these specimens shared one ribotype (U5 (MH924769), U9 (MH924770). U11 
(MH924771), U12 (MH924772)) and were very similar to a sample of Ranunculus penicillatus obtained from the GenBank ${ }^{\circledR}$ database (KR996526). Based on morphological characters and molecular data, we treated these plants as R. penicillatus.

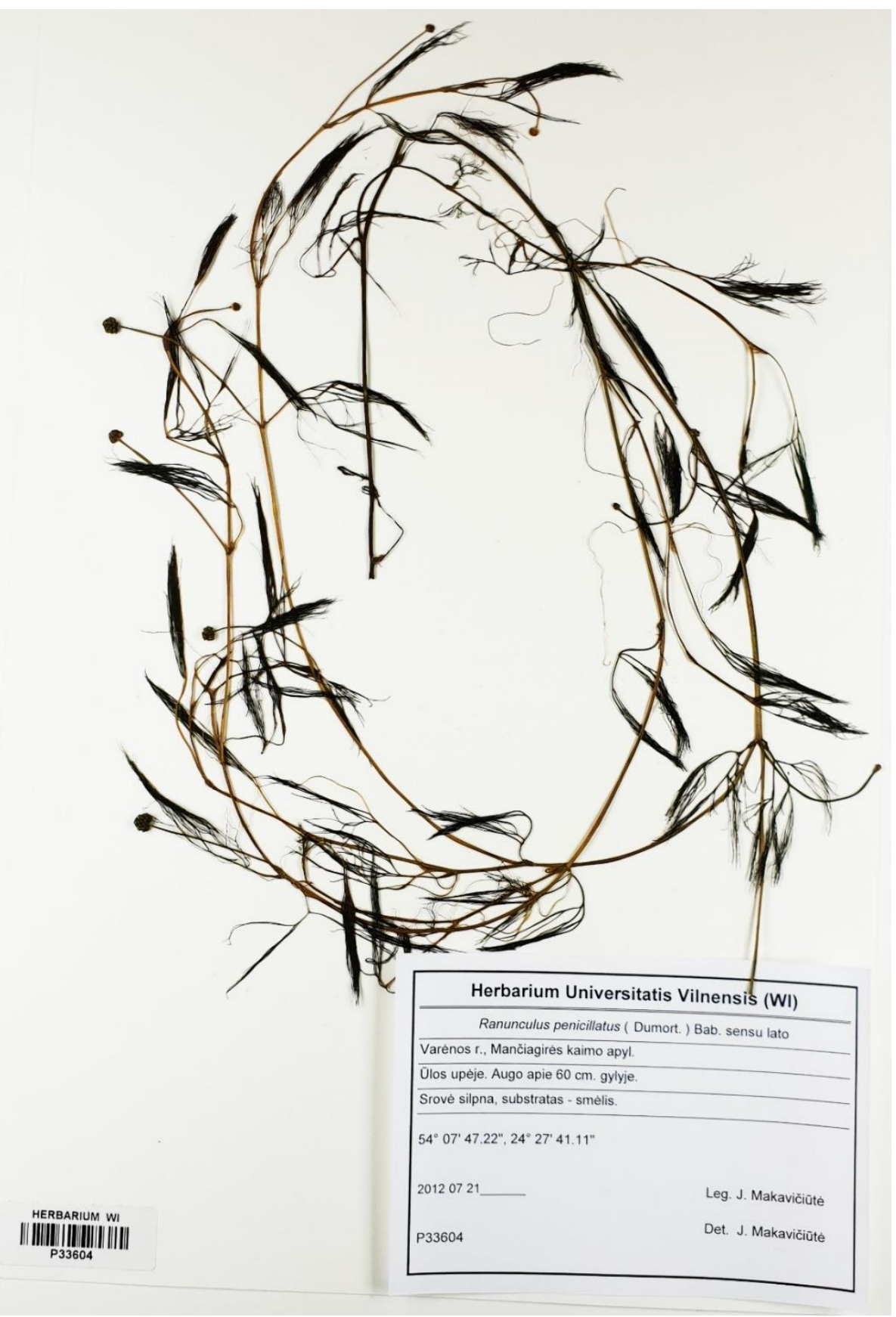

Figure 3. General appearance of putative Ranunculus penicillatus s.l. plant with capillary leaves only, from the Ula River. 


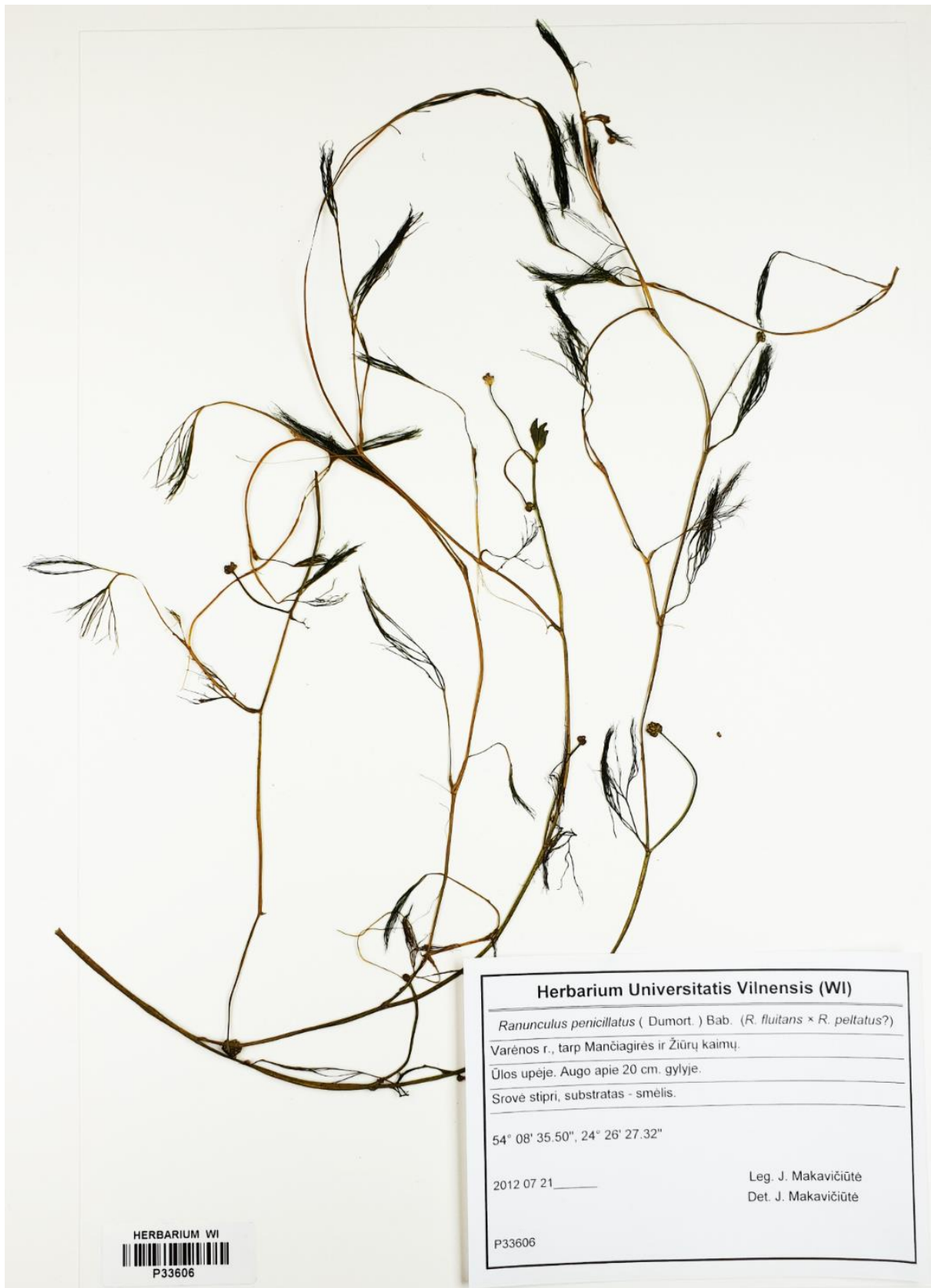

Figure 4. General appearance of putative Ranunculus penicillatus s.l. plant with capillary leaves and intermediate leaves from the Ula River.

In the Skroblus River, heterophyllous plants with developed intermediate leaves and flaccid capillary leaves with numerous ultimate segments occurred (Figure 5). The plants were sterile (weakly developed peduncles with empty heads). They exhibited five ribotypes (Table 3). The cluster analysis of the ITS region sequences of Ranunculus from the Skroblus sampling sites showed the highest similarity of sequences of the two ribotypes, S6 (MT015511) and S7 (MT015510), to sequences of $R$. penicillatus from the Ula River (U5, 9, 11, and 12 (MH924769-924772)) and was obtained from the GenBank ${ }^{\circledR}$ database (KR996528), whereas sequences of the remaining three ribotypes clustered with sequences of R. circinatus from the Gruda River (G6 (MH924773)) and were obtained from the GenBank ${ }^{\circledR}$ database (KF719061) (Figure 1). 


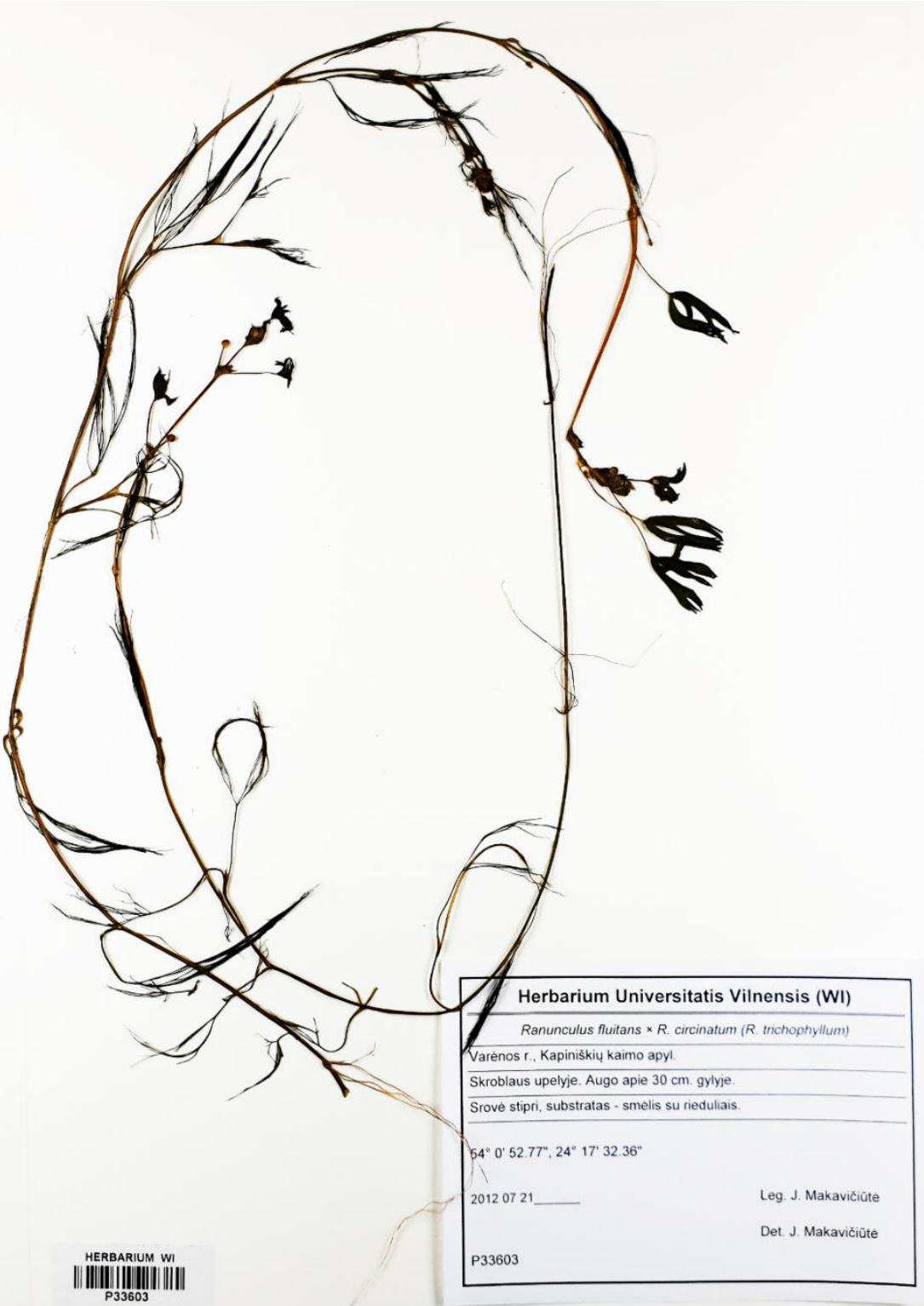

Figure 5. General appearance of putative Ranunculus hybrid with capillary and intermediate leaves from the Skroblus River.

Cluster analysis revealed that specimens with general morphology of R. penicillatus s.l. from the Ula and Skroblus rivers differ by their origin. Plants from the Ula River were fertile and they shared the same one ribotype similar to R. penicillatus. Plants from the Skroblus River were sterile and they shared sequences belonging to two groups, the first being similar to sequences of $R$. circinatus and the second to R. penicillatus. Sterility and such differentiation of the ITS sequences in the Skroblus River specimens suggest their hybrid origin.

PCoA was used to visualize the relationships among the supposed parental species and putative hybrid from Skroblus population. The two first coordinates described approximately $82.39 \%$ of the total genetic variability. Coordinate 1 explained $67.0 \%$ of the total variation and Coordinate 2 explained $15.39 \%$ (Figure 6). 


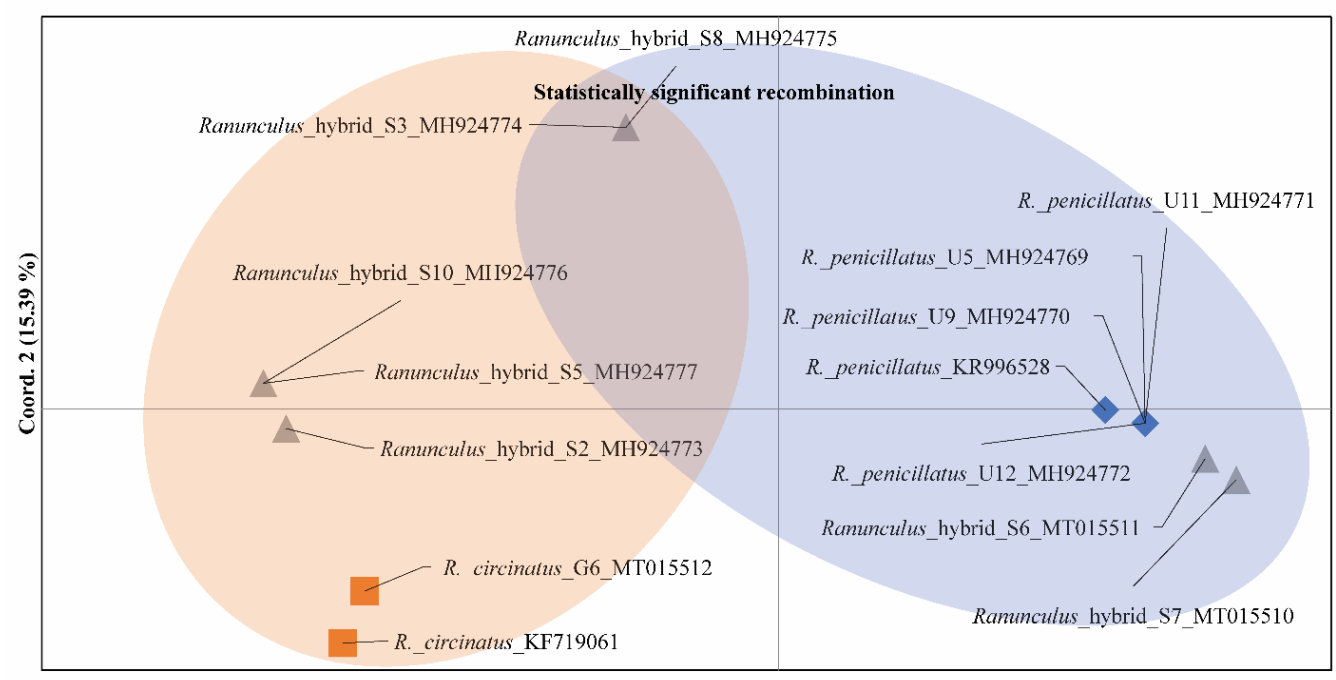

Coord. $1(67.0 \%)$

Figure 6. Principal coordinate analysis of supposed parental species (R. circinatus (orange) and $R$. penicillatus (blue)) and Ranunculus hybrid from the Skroblus River (grey).

The supposed parental species (R. circinatus and R. penicillatus) were grouped separately (Figure 6: orange zone-R. circinatus; blue zone-R. penicillatus). Principal coordinate analysis (PCoA) also revealed that hybrid plants from the Skroblus River were genetically differentiated. Ranunculus hybrids S2, S5, and S10 were closely located to R. circinatus, whereas, Ranunculus hybrids S6 and S7 were closely located to R. penicillatus. Ranunculus hybrids S3 and S8 were located distantly (Figure 6).

The maximum chi-square test (between two sequences and a putative derived sequence) showed that exactly Ranunculus hybrids S3 and S8 had statistically significant recombination after nucleotide 202 (Max Chi-squared $=10.4318, p<0.0001$ ). A statistically significant possible recombination was not detected in the remaining Skroblus individuals.

The alignment of cpDNA sequences determined from the cloned fragments that represented the full rpl32-trnL region was 966 bp long. Analysis of sequencing data revealed 15 variable and 951 conserved sites. All variable sites were identified as single nucleotide polymorphisms (SNPs). Additionally, single base pair insertion/deletion (indel) was identified in four individuals and 3-bp indel in three individuals. The analysis of this region did not show any tendencies of the connections of Skroblus hybrids and supposed parental species R. circinatus and R. penicillatus (i.e., maternal inheritance), because all sequences generally look similar.

\subsection{Chromosome Numbers of R. circinatus, R. penicillatus, and Putative Hybrid}

Karyological investigation demonstrated that specimens of putative hybrid $R$. circinatus $\times R$. penicillatus from the Skroblus River were tetraploid $(2 n=32)$, whereas the specimens of $R$. circinatus from the Gruda River were diploid $(2 n=16)$ and $R$. penicillatus from the Ula River were hexaploid $(2 \mathrm{n}=48)$ (Figure 7). 


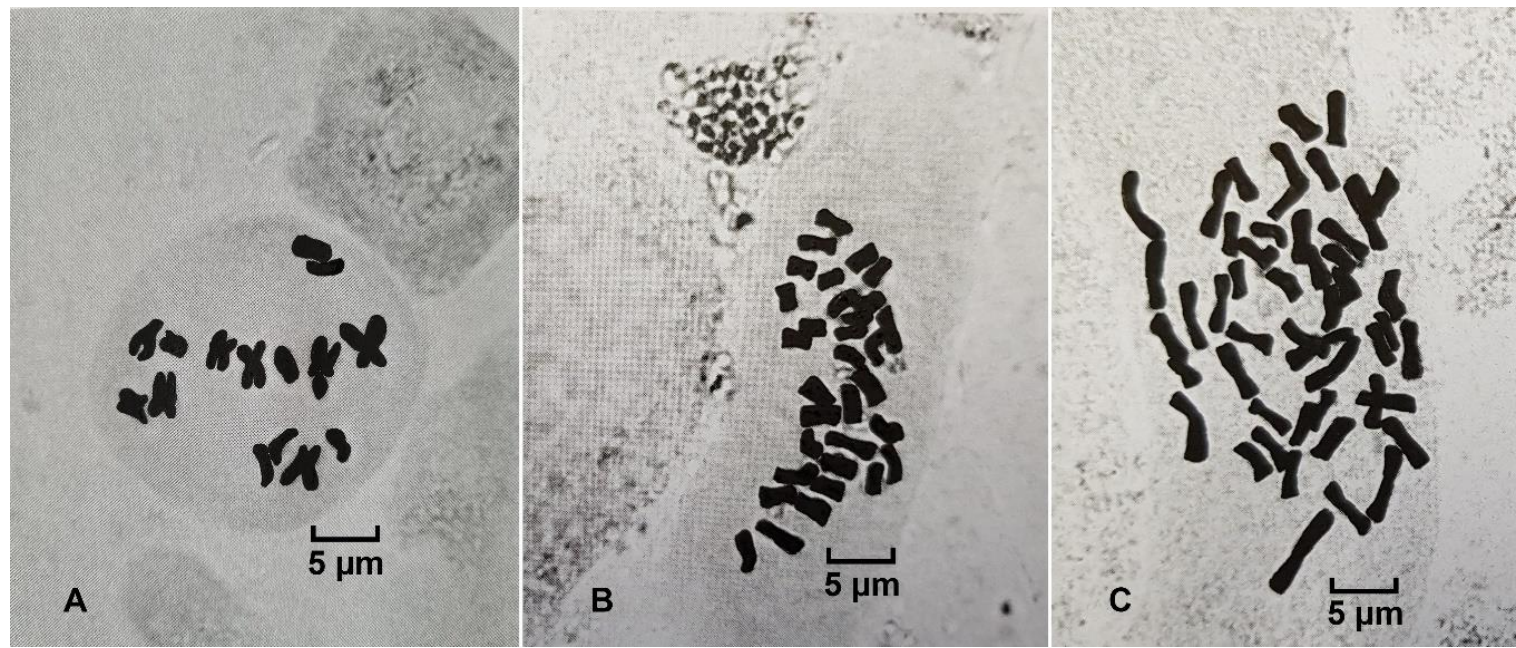

Figure 7. The metaphase plates of $R$. circinatus $(2 n=16)$ from the Gruda River $(A)$, putative $R$. circinatus $\times$ R. penicillatus $(2 \mathrm{n}=32)$ from the Skroblus River $(\mathbf{B})$, and $R$. penicillatus $(2 \mathrm{n}=48)$ from the Ula River (C).

\section{Discussion}

In this research, we tested the taxonomical belonging of river Batrachium Ranunculus plants with capillary leaves only (homophyllous) and differently expressed intermediate leaves (heterophyllous) occurring in three different rivers (Gruda, Skroblus, and Ula) of the same catchment area. Historically, before the last ice age, the Merkys River and its tributaries Gruda, Skroblus, and Ula formed one large river differentiated into separate rivers only after the ice age [17]. This event could be very important for the microevolution of aquatic plants. Thus, in the Skroblus River, Stuckenia $\times$ fennica (Hagstr.) Holub (S. filiformis (Pers.) Börner $\times$ S. vaginata (Turcz.) Holub) occurs without both parental species [18]. This is a well-known example of the occurrence of sterile hybrids in postglacial areas without parental species since the last glaciation [19]. Hybrid Ranunculus detected in this study grow in the Skroblus River together with Stuckenia $\times$ fennica and this could represent a similar case of sterile hybrids of ancient (glacial) origin.

The hybrid Ranunculus from the Skroblus River has a phenotype more similar to one parental species (typical R. penicillatus). However, typical heterophyllous R. penicillatus with developed floating, intermediate, and capillary leaves have never been recorded in Lithuanian rivers. However, except the Skroblus River, plants with only capillary or rarely capillary and weakly developed intermediate leaves treated as R. penicillatus (but never with "true" floating and clearly expressed intermediate leaves) often were found in the rivers of the Merkys basin [20]. Such a kind of morphological incongruence of the Skroblus hybrid phenotype and the Merkys basin R. penicillatus could be a result of morphological variation of the former caused by hybridization and specific river environment.

Inbreeding, cleistogamy, and clonal reproduction characteristics for Batrachium can decrease intrapopulation diversity [21] and could explain the low genetic diversity, but high genetic differentiation within the studied plants group. It is well known that small disjunct populations can be affected by genetic drift and inbreeding that also increase interpopulation differences $[16,22,23]$. Although, our study did not identify ISSR bands specific for different morphotypes and no significant molecular differences were detected by hierarchical AMOVA between groups of heterophyllous and homophyllous plants $(p=0.3)$.

The ITS region sequencing of heterophyllous hybrid plants sampled from the Skroblus River revealed five ribotypes that showed high similarity with the ribotypes of $R$. circinatus and $R$. penicillatus from other rivers and ITS regions of these species retrieved from GenBank ${ }^{\circledR}$. These results could indicate that plants from the Skroblus arose from crossings of $R$. penicillatus, which according to [1] consists of allopolyploids originating from the hybrids of $R$. fluitans with $R$. aquatilis, R. peltatus, 
and R. trichophyllus, with rigid-leaved species $R$. circinatus. This was somehow unexpected because there were no clear morphological characters of R. circinatus in the Skroblus plants. In addition, the sequences of plants with intermediate leaves from the Skroblus River were not similar to those in a previous molecular analysis which allowed the detection of hybrid $R$. fluitans $\times R$. peltatus from Poland [4]. Bobrov et al. [5] analyzed seven samples of $R$. penicillatus that did not show interindividual polymorphism in the ITS region. We identified this ribotype in the Ula River population with only differences in the absence of three polymorphic sites (positions 32 with $A$ or $G, 55$ with $C$ or $T, 72$ with $\mathrm{C}$ or $\mathrm{T}$ ) and one transition of $\mathrm{C}$ instead of $\mathrm{T}$ at the $108 \mathrm{bp}$ position. In the same publication of [5], five ribotypes were detected in $R$. trichophyllus. These ribotypes, considering the possible role of this species in the origin of R. penicillatus s.l., could explain the increase in ribotype polymorphism (five ribotypes) of aquatic Ranunculus from the Skroblus River. Additionally, it could arise as a result of multiple hybridization events, which implies not only phenotypic differences but also high differences at the molecular level $[1,4,5,9]$. The hybrid origin of Ranunculus from the Skroblus River from the lineage of $R$. penicillatus s. str. similar to the Ula River population and R. circinatus, indicated by genome differentiation and recombination, is confirmed by a maximum Chi-square recombination test.

The long formation of different genotypes could have been stabilized by clonal reproduction, but clonality may have an impact on the distribution of genetic diversity in natural populations [24]. The clonal reproduction may allow such sterile hybrids to form persistent populations and stabilize hybrid lineages [24,25]. Levels of genetic variability in sterile hybrids are determined by the amount of genetic diversity initially present in the parents, the frequency of hybrid formation events, the intensity of competitive exclusion among clones, the reduced effective population size in clonal populations, and somatic mutation [26,27]. Caetano-Anollés [27] notes that genome-wide mutation levels increase in vegetative culture. An accumulation of mutations within plants that are multiplying vegetatively at high rates could have important consequences for their biology and could be the cause of high genetic diversity [27-29]. Therefore, we also cannot exclude that besides recombination, additional sequence diversity of the sterile Skroblus individuals could have appeared from independent mutation events. This fact demonstrated again the complicated origin of the group of $R$. penicillatus and the interspecific hybridization during its evolution.

All obtained $r p l 32-t r n \mathrm{~L}$ region sequences were similar. This is interesting because the rigid-leaved species, including $R$. circinatus, usually have very distinct sequences of plastid regions (e.g., [5]). This result can only be explained by the fact that the studied river population of $R$. circinatus can inherit non-characteristic plastid DNA as a trace of some hybridization in the past.

According to [8], polyploidy is frequent within aquatic Ranunculus, covering five ploidy levels ranging from diploids $(2 n=16)$ to hexaploidy $(2 n=48)$. Differences in ploidy level often have significant effects on phenotypic and reproductive traits [30]. Our study of chromosome numbers confirmed the hypothesis that Ranunculus with intermediate leaves from the Skroblus River (tetraploid) is a sterile hybrid between R. penicillatus (hexaploid) and R. circinatus (diploid). We may expect fertility to some extent in tetraploid hybrids, but, evidently, strong evolutionary differences between rigid-leaved species of the $R$. circinatus group with the remaining lineages of Batrachium caused sterility of this hybrid form [31].

\section{Materials and Methods}

\subsection{Plant Sampling}

Aquatic Ranunculus plant were sampled from stretches of three different rivers (each 100 m long) belonging to the Merkys River basin (southeast Lithuania): Gruda at $54^{\circ} 07^{\prime} 09.25^{\prime \prime} \mathrm{N}, 24^{\circ} 18^{\prime} 17.52^{\prime \prime} \mathrm{E}$; Ula at $54^{\circ} 07^{\prime} 45.42^{\prime \prime} \mathrm{N}, 24^{\circ} 27^{\prime} 44.88^{\prime \prime} \mathrm{E}$; Skroblus at $54^{\circ} 0^{\prime} 55.05^{\prime \prime} \mathrm{N}, 24^{\circ} 17^{\prime} 38.4^{\prime \prime} \mathrm{E}$ (Figure 8). 


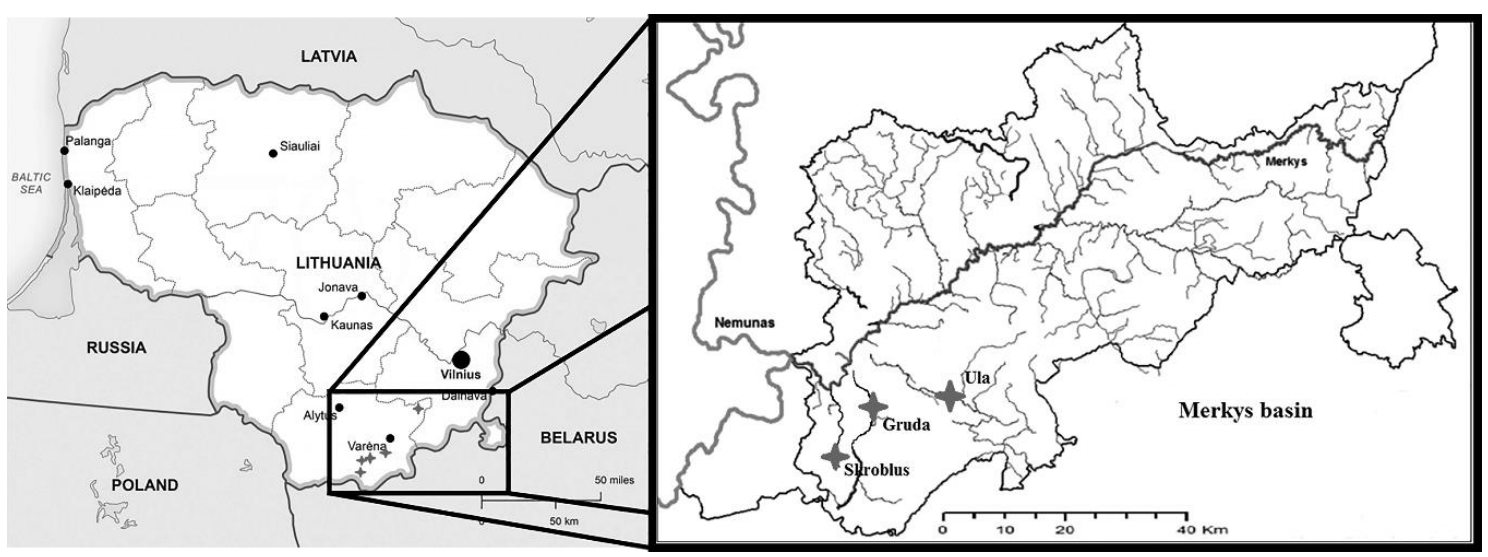

Figure 8. Map of the sampling sites from the Merkys River basin: Ula, Skroblus, and Gruda Rivers.

Samples were taken during July and August 2019 when plants are usually expected to have generative structures formed. A total of 33 samples of Ranunculus were collected and DNA was extracted for ISSR-PCR analysis: 11 plant samples from the Gruda River (G1-11), 10 from the Skroblus River (S1-10), and 12 from the Ula River (U1-12).

Eight samples of heterophyllous plants (with capillary and intermediate leaves) from the rivers Skroblus (S2, S3, S5, S6 S7, S8, S10) and Ula (U5) and 6 samples of homophyllous plants (with capillary leaves only) from the rivers Gruda (G1, G6, G11) and Ula (U9, U11, U12) were used for ITS and rpl32-trn L region sequencing.

\subsection{DNA Extraction and ISSR-PCR Amplification}

Fresh plant leaves, $80-100 \mathrm{mg}$, were used for DNA isolation, according to a modified CTAB method [32]. The DNA amplification proceeded in a final volume of $10 \mu \mathrm{L}$, including $4 \mu \mathrm{L}$ of DNA $(5 \mathrm{ng} / \mu \mathrm{L}), 1.0 \mu \mathrm{L}$ of $10 \times$ Taq buffer with $\mathrm{KCl}, 1.0 \mu \mathrm{L}$ of dNTP mix $(2 \mathrm{mM}), 1.2 \mu \mathrm{L}$ of $\mathrm{MgCl}_{2}(25 \mathrm{mM})$, $1.0 \mu \mathrm{L}$ of a specific primer (1.0 OD unit) $0.08 \mu \mathrm{L}$ of Taq polymerase $(5 \mathrm{U} / \mu \mathrm{L}))$ (Thermo Fisher Scientific Baltics, Vilnius, Lithuania), and $1.72 \mu \mathrm{L}$ of deionized water $(18.3 \mathrm{M} \Omega)$. ISSR-PCR was performed using a Mastercycler Personal (Eppendorf, Germany) thermocycler, as described earlier [16]: initial denaturation at $94{ }^{\circ} \mathrm{C}$ for $7 \mathrm{~min} ; 32$ cycles of: $94{ }^{\circ} \mathrm{C}$ for $30 \mathrm{~s}$, specific temperature for each primer for $45 \mathrm{~s}, 72{ }^{\circ} \mathrm{C}$ for $2 \mathrm{~min}$; ending with $72{ }^{\circ} \mathrm{C}$ for $10 \mathrm{~min}$. In total, 27 different ISSR primers (ISSR I-28, ISSR I-39, Ward 1, Ward 2, ISSR I-34, ISSR I-50, Arcade 1, Arcade 4, ISSR-C, UBC 881, ISSR-E, ISSR-A, ISSR-D, ISSR-B, ISSR-G, ISSR-F, ISSR-H, ISSR-18, ISSR-32, ISSR-29, UBC807, UBC808, UBC810, UBC825, UBC827, UBC834 and UBC847) were tested; 10 primers (ISSR I-28 ((GT) $\left.)_{6} \mathrm{CG}\right)$, ISSR I-39 ((AGC) $\left.{ }_{4} \mathrm{AC}\right)$, Ward $1\left((\mathrm{AC})_{8} \mathrm{~T}\right)$, Ward $2\left((\mathrm{AC})_{8} \mathrm{G}\right)$, ISSR I-34 ((AGC) $\left.{ }_{4} \mathrm{GG}\right)$, ISSR I-50 (CCA(GCT) $\left.)_{4}\right)$, Arcade $1\left((\mathrm{CA})_{8} \mathrm{GT}\right)$, Arcade $4\left((\mathrm{GA})_{8} \mathrm{TC}\right)$, ISSR-C ((AG) $\left.)_{8} \mathrm{TG}\right), \mathrm{UBC} 881$ (GGG(TGGG) $\left.\left.{ }_{2} \mathrm{TGTG}\right)\right)$ that produced clear and reproducible ISSR banding profiles were chosen for further analysis. The results of the amplification were visualized using 1.2\% TBE-agarose gels stained with ethidium bromide. Images of the gel were made using the BioDocAnalyse (Biometra, Germany) system. Using the GeneRuler DNA LadderMix marker (Thermo Fisher Scientific Baltics, Lithuania), the bands in the gels were scored from 300 to 1800 $\mathrm{bp}$. The reproducibility of amplified ISSR bands was examined by at least two independent repeats of PCR analysis and gel electrophoresis for all samples with all 10 primers. The comparison of banding pattern between two repeats resulted in 1245 phenotypic comparisons. The error rate was $1.1 \%$. Only reproducible bands (1231) were included in the binary matrix and were used for analysis. The binomial matrix (1/0) of scored bands for further analysis was prepared, in which 1 indicated the presence of a band, and 0 indicated the absence. 


\subsection{ITS and rpl32-trnL Regions Sequencing}

Analyses of the ribosomal DNA ITS region (14 samples) and the plastid rpl32-trnL region (14 samples) were performed. Primers ITS1 (5'-TCCGTAGGTGAACCTGCGG-3') and ITS4 (5'-TCCTCCGCTTATTGATATGC-3') were used for the amplification of the nuclear DNA region [33]. The PCR was performed as follows: initial denaturation at $94^{\circ} \mathrm{C}$ for $2 \mathrm{~min} ; 30$ cycles of: $94{ }^{\circ} \mathrm{C}$ for $1 \mathrm{~min}$, $54{ }^{\circ} \mathrm{C}$ for $30 \mathrm{~s}$, DNA synthesis at $72{ }^{\circ} \mathrm{C}$ for $2 \mathrm{~min}$; ending with $72{ }^{\circ} \mathrm{C}$ for $5 \mathrm{~min}$. Respectively, the primers $r p l 32$ ( $5^{\prime}$-AGTTCCAAAAAAACGTACTTC- $3^{\prime}$ ) and $t r n$ L (UAG) (5'-CTGCTTCCTAAGAGCAGCGT- $3^{\prime}$ ) were used for the amplification of the non-coding chloroplast DNA region [34]. The PCR was performed as follows: initial denaturation at $80^{\circ} \mathrm{C}$ for $5 \mathrm{~min}$; 30 cycles of: $95^{\circ} \mathrm{C}$ for $1 \mathrm{~min}$, primer annealing at $50^{\circ} \mathrm{C}$ for $1 \mathrm{~min}$, DNA synthesis at followed by a ramp of $0.3{ }^{\circ} \mathrm{C} / \mathrm{s}$ to $65^{\circ} \mathrm{C}$, and primer extension at $65{ }^{\circ} \mathrm{C}$ for $4 \mathrm{~min}$; ending with $65^{\circ} \mathrm{C}$ for $5 \mathrm{~min}$. The preparation of amplified DNA fragments for sequencing was conducted as described earlier in [35]. Briefly, PCR products were visualized in a $1 \%$ TAE-agarose gel, and the bands were cut out and purified using a GeneJET Gel Extraction Kit (Thermo Fisher Scientific Baltics, Lithuania). To check the concentration and purity of the purified PCR products, a NanoDrop ${ }^{\mathrm{TM}}$ spectrophotometer was used (Thermo Fisher Scientific, Waltham, MA, USA). The purified DNA fragments were introduced to pTZ57R/T vectors using an InsTAclone PCR Cloning Kit (Thermo Fisher Scientific Baltics, Lithuania), following the manufacturer's protocol. Plasmid DNA was isolated from 2-3 clones per sample using a Plasmid Miniprep DNA Purification Kit (Thermo Fisher Scientific Baltics, Lithuania) following the manufacturer's protocol. The inserts were sequenced using primer M13/pUC (-46), 22-mer, and the reverse primer M13/pUC (-46), 24-mer, at the BaseClear B.V. (Leiden, The Netherlands) sequencing center.

\subsection{Cytological Analysis}

Material for cytological analysis was collected in September 2019 from natural populations in the Gruda, Skroblus, and Ula rivers, where putative parental and hybrid plants occur. The tips of roots were taken from 10 plants from each river and 15 roots from each plant. In total, we analyzed 150 tips of roots of each taxon.

The root tips were pre-treated in a $0.1 \%$ colchicine solution for four hours and then fixed in a $3: 1$ mixture of $96 \%$ ethanol and acetic acid for two hours. The root tips were transferred into $70 \%$ ethanol. In the laboratory, root tips were stained by placing in $4 \%$ iron-ammonium alum for $10 \mathrm{~min}$ at room temperature and brought to a boil in $1 \%$ acetic hematoxylin twice. The squashed chromosome preparations of root tips were made with chloral hydrate (1:1) by using a standard root tip squash technique [36]. The metaphases were studied and photographed under an EVOS XL Digital inverted brightfield and phase contrast microscope with an image acquisition system.

\subsection{Data Analyses}

For the ISSR dataset processing, Nei's gene diversity (h) and Shannon's information index (I) were calculated using the software PopGene [37]. Expected heterozygosity (He) and Wright's fixation index (Fst) were estimated using the software AFLP-SURV 1.0 [38]. The band richness (Br) and proportion of polymorphic loci (PLP 5\% level) using the rarefaction method for 8 individuals per population were calculated with AFLP-DIV v.1.1 [39].

Principal coordinate analysis (PCoA) was performed using the ITS dataset, and analysis of molecular variance (AMOVA) was performed using the ISSR dataset. Both analyses were performed with the software GenAlEx [40].

The MEGA $X$ ver.10.1.8. program [41] was employed to align sequencing results with other Batrachium group ITS region and rpl32-trnL sequences from the NCBI GenBank database, which were extracted using the BLAST ${ }^{\circledR}$ [42] tool. For analysis of the ITS region, the maximum likelihood (ML) method was performed with a Tamura 3-parameter model, which was selected based on the highest BIC (Bayesian Information Criterion) score. Bootstrap support values were computed for 1000 replicates. 
For searching of recombinant sequences, the maximum Chi-square test (one derived and two parental sequences, significance test with 1000 replicates) for putative chimeras was implemented in START ver. 2 [43].

\section{Conclusions}

In conclusion, we did not reveal any evidence of ISSR polymorphisms associated with the development of intermediate leaves. The results of ITS analysis implied that genetic differences of the studied plants were produced by interspecific hybridization. Additionally, the studies revealed that heterophyllous plants from Skroblus River are an ancient, sterile hybrid between $R$. circinatus and R. penicillatus, which was not known to date [7], whereas the remaining homophyllous or almost homophyllous plants belong to fertile $R$. circinatus, R. fluitans, and R. penicillatus. Despite the fact that a new hybrid combination $R$. circinatus $\times R$. penicillatus was discovered, it is impossible to make a formal description of a new nothotaxon because its morphological characters almost fully overlap with allopolyploid R. penicillatus.

The discovery of such an unusual sterile hybrid between diploid rigid-leaved species $R$. circinatus and allotetraploid R. penicillatus also support the point of view that network evolution by repeated hybridization events is one of the major mechanisms of speciation in Batrachium [7], especially in rivers and streams, which play a role of "evolutionary incubator" for such newly arising hybrids and polyploids [8].

Author Contributions: Conceptualization, J.B., A.A.B.; data curation, J.B., A.A.B., D.N.; methodology, J.B., A.A.B., D.N., Z.S., D.Ž.; assistance with chromosome analysis, A.S.; software, J.B., A.A.B., D.N.; writing-original draft, J.B., A.A.B.; writing—review and editing, J.B., A.A.B., D.N., Z.S., D.Ž. All authors have read and agreed to the published version of the manuscript.

Funding: This research was funded by a grant (No. S-SIT-20-1) from the Research Council of Lithuania research. The work of A. A. Bobrov partly was held within the state assignment of IBIW RAS (theme AAAA-A18-118012690095-4) and with support by the Russian Foundation for Basic Research (project 19-04-01090-a).

Acknowledgments: The authors would like to thank Jolanta Patamsyte and Veronika Dedonytè (Vilnius University, Life Sciences Center) for help with chromosome analysis.

Conflicts of Interest: The authors declare no conflict of interest.

\section{References}

1. Cook, C.D.K. A monograpfic study of Ranunculus subgenus Batrachium (DC) A. Gray. In Mitteilungen der Botanischen Staatssammlung, München; Botanische Staatssammlung München: München, Germany, 1966; pp. 4-93.

2. Webster, S.D. Ranunculus penicillatus (Dumort.) Bab. in Great Britain and Ireland. Watsonia 1988, 17, 1-22.

3. Cook, C.D.K. Studies in Ranunculus subgenus Batrachium (DC.) A. Gray II. General morphological considerations in the taxonomy of the subgenus. Watsonia 1963, 5, 294-303.

4. Zalewska-Gałosz, J.; Jopek, M.; Ilnicki, T. Hybridization in Batrachium group: Controversial delimitation between heterophyllous Ranunculus penicillatus and the hybrid Ranunculus fluitans $\times$ R. peltatus. Aquat. Bot. 2015, 120, 160-168. [CrossRef]

5. Bobrov, A.A.; Zalewska-Gałosz, J.M.; Movergoz, E.A. Ranunculus schmalhausenii (section Batrachium, Ranunculaceae), a neglected water crowfoot endemic to Fennoscandia-A case of rapid hybrid speciation in postglacial environment of North Europe. Phytotaxa 2015, 233, 101-138. [CrossRef]

6. Lambertini, C.; Gustafsson, M.H.G.; Baattrup-Pedersen, A.; Riis, T. Genetic structure of the submersed Ranunculus baudotii (sect. Batrachium) population in a lowland stream in Denmark. Aquat. Bot. 2017, 136, 186-196. [CrossRef]

7. Wiegleb, G.; Bobrov, A.; Zalewska-Gałosz, J. A taxonomic account of Ranunculus section Batrachium (Ranunculaceae). Phytotaxa 2017, 319, 1-55. [CrossRef]

8. Prančl, J.; Koutecky, P.; Lučanova, M. Cytotype variation, cryptic diversity and hybridization in Ranunculus sect. Batrachium revealed by flow cytometry and chromosome numbers. Preslia 2018, 90, 195-223. [CrossRef] 
9. Lansdown, R.V. The Identity of Ranunculus Subgenus Batrachium in the River Itchen; Environment Agency, Southern Region: Berkshire, UK, 2007.

10. Tzvelev, N.N. (Ed.) Rod 26. Batrachium S. F. Gray. In Konspekt Flory Vostochnoi Evropy. T. 1; KMK Press: Moscow, Russia, 2012.

11. Wang, B.; Li, W.; Wang, J. Genetic diversity of Alternanthera philoxeroides in China. Aquat. Bot. 2005, 81, 277-283. [CrossRef]

12. Kameyama, Y.; Ohara, M. Predominance of clonal reproduction, but recombinant origins of new genotypes in the free-floating aquatic bladderwort Utricularia australis f. tenuicaulis (Lentibulariaceae). J. Plant Res. 2006, 119, 357-362. [CrossRef]

13. Pollux, B.J.A.; Jong, M.D.E.; Steegh, A.; Verbruggen, E.; Van Groenendael, J.M.; Ouborg, N.J. Reproductive strategy, clonal structure and genetic diversity in populations of the aquatic macrophyte Sparganium emersum in river systems. Mol. Ecol. 2007, 16, 313-325. [CrossRef]

14. Kaplan, Z. Hybridization of Potamogeton species in the Czech Republic: Diversity, distribution, temporal trends and habitat preferences. Preslia 2010, 82, 261-287.

15. Telford, A.; O'Hare, M.T.; Cavers, S.; Holmes, N. Can genetic bar-coding be used to identify aquatic Ranunculus L. subgenus Batrachium (DC) A. Gray? A test using some species from the British Isles. Aquat. Bot. 2011, 95, 65-70. [CrossRef]

16. Butkuvienė, J.; Sinkevičienè, Z.; Naugžemys, D.; Patamsytė, J.; Žvingila, D. Genetic diversity of Batrachium (Ranunculaceae) species reveals the necessity of their protection in Lithuanian rivers. Aquat. Bot. 2017, 142, 61-70. [CrossRef]

17. Baubinienè, A. Merkio ir jo Intaku Senvagès. Lietuvos Valsčiai. Valkininkai. Available online: http: //www.llt.lt/pdf/valkininkai/merkio_senvage.pdf (accessed on 27 October 2020).

18. Data of National River Monitoring. Available online: http://vanduo.gamta.lt/cms/index?rubricId=a65cce5b64c7-445f-883e-af3e11213469 (accessed on 15 September 2020).

19. Bobrov, A.A. Potamogeton $\times$ fennicus (P. filiformis $\times$ P. vaginatus, Potamogetonaceae) in East Europe. Komarovia 2007, 5, 1-23.

20. Butkuvienè, J.; Sinkevičienè, Z.; Žvingila, D. Batrachium (Ranunculaceae) in the rivers of Lithuania. Bot. Lith. 2014, 20, 46-56. [CrossRef]

21. Wang, Y.H.; Chen, J.M.; Xu, C.; Liu, X.; Wang, Q.F.; Motley, T.J. Population genetic structure of an aquatic herb Batrachium bungee (Ranunculaceae) in the Hengduan Mountains of China. Aquat. Bot. 2010, 92, 221-225. [CrossRef]

22. Husband, B.C.; Barrett, S.C.H. Effective population size and genetic drift in tristylous Eichhornia paniculata (Pontederiaceae). Evolution 1992, 46, 1875-1890. [CrossRef]

23. Sampson, J.F.; Hankinson, M.; McArthur, S.; Tapper, S.; Longley, M.; Gibson, N.; Yates, C.; Byrne, M. Long-term 'islands' in the landscape: Low gene flow, effective population size and genetic divergence in the shrub Hakea oldfieldii (Proteaceae). Bot. J. Linn. Soc. 2015, 179, 319-334. [CrossRef]

24. Marques, I.; Felinger, G.N.; Martins-Loucao, M.A.; Aquilar, J.F. Fitness in Narcissus hybrids: Low fertility is overcome by early hybrid vigour, absence of exogenous selection and high bulb propagation. J. Ecol. 2011, 99, 1508-1519. [CrossRef]

25. Mallet, J. Hybrid speciation. Nature 2007, 446, 279-283. [CrossRef]

26. Marin, M.V.; Lye, G.C. Hybridisation and genetic diversity in introduced Mimulus (Phrymaceae). Heredity 2013, 110, 111-122. [CrossRef] [PubMed]

27. Caetano-Anollés, G. High genome-wide mutation rates in vegetatively propagated bermudagrass. Mol. Ecol. 1999, 8, 1211-1221. [CrossRef]

28. Carino, D.A.; Dahler, C.C. Genetic variation in an apomictic grass, Heteropogon contortus, in the Hawaiian Islands. Mol. Ecol. 1999, 8, 2127-2132. [CrossRef] [PubMed]

29. Sarla, N.; Siddiq, E.A.; Pradeep-Reddy, M.N. Inter simple sequence repeat (ISSR) polymorphism and its application in plant breeding. Euphytica 2002, 128, 9-17. [CrossRef]

30. Husband, B.C.; Baldwin, S.J.; Suda, J. The incidence of polyploidy in natural plant populations: Major patterns and evolutionary processes. Plant Gen. Div. 2013, 2, 255-276. [CrossRef]

31. Paunl, O.; Forest, F.; Fay, F.M.; Chase, M.W. Hybrid speciation in angiosperms: Parental divergence dives ploidy. New Phytol. 2009, 182, 507-518. [CrossRef] 
32. Doyle, J.J.; Doyle, J.J. A rapid DNA isolation procedure for small quantities of fresh leaf tissue. Phytochem. Bull. 1987, 19, 11-15.

33. White, T.J.; Bruns, T.; Lee, S.; Taylor, J. Amplification and direct sequencing of fungal ribosomal RNA genes for phylogenetics. In PCR Protocols: A Guide to Methods and Applications; Academic Press: New York, NY, USA, 1990; Volume 18, pp. 315-322. [CrossRef]

34. Shaw, J.; Lickey, E.B.; Schilling, E.E.; Small, R.L. Comparison of whole chloroplast genome sequences to choose noncoding regions for phylogenetic studies in angiosperms: The tortoise and the hare III. Am. J. Bot. 2007, 94, 275-288. [CrossRef]

35. Patamsytė, J.; Naugžemys, D.; Čèsnienè, T.; Kleizaitè, V.; Demina, O.N.; Mikhailova, S.I.; Agafonov, V.A.; Žvingila, D. Evaluation and comparison of the genetic structure of Bunias orientalis populations in their native range and two non-native ranges. Plant Ecol. 2018, 219, 101-114. [CrossRef]

36. Smirnov, Y.A. Accelerated methods for studying somatic chromosomes in fruit trees. Tsitologia 1968, 10, 1132-1134.

37. Yeh, F.C.; Boyle, T.J.B. Population Genetic Analysis of Codominant and Dominant Markers and Quantitative Traits. Belg. J. Bot. 1997, 129, 157-163.

38. Vekemans, X.; Beauwens, T.; Lemaire, M.; Roldan-Ruiz, I. Data from amplified fragment length polymorphism (AFLP) markers show indication of size homoplasy and of a relationship between degree of homoplasy and fragment size. Mol. Ecol. 2002, 11, 139-151. [CrossRef] [PubMed]

39. Coart, E.; Glabeke, V.S.V.; Petit, R.J.; Bockstaele, V.E.V.; Roldan-Ruiz, I. Range wide versus local patterns of genetic diversity in hornbeam (Carpinus betulus L.). Conserv. Genet. 2005, 6, 259-273. [CrossRef]

40. Peakall, R.; Smouse, P.E. GenAlEx 6.5: Genetic analysis in Excel. Population genetic software for teaching and research-An update. Bioinformatics 2012, 28, 2537-2539. [CrossRef] [PubMed]

41. Kumar, S.; Stecher, G.; Li, M.; Knyaz, C.; Tamura, K. MEGA X: Molecular Evolutionary Genetics Analysis across Computing Platforms. Mol. Biol. Evol. 2018, 35, 1547-1549. [CrossRef]

42. Madden, T.L.; Tatusov, R.L.; Zhang, J. Applications of network BLAST server. Meth. Enzymol. 1996, 266, 131-141. [CrossRef]

43. Jolley, K.A.; Feil, E.J.; Chan, M.S.; Maiden, M.C. Sequence type analysis and recombination test (START). Bioinformatics 2001, 17, 1230-1231. [CrossRef]

Publisher's Note: MDPI stays neutral with regard to jurisdictional claims in published maps and institutional affiliations.

(C) 2020 by the authors. Licensee MDPI, Basel, Switzerland. This article is an open access article distributed under the terms and conditions of the Creative Commons Attribution (CC BY) license (http://creativecommons.org/licenses/by/4.0/). 